\title{
APLIKASI ZERO-ONE GOAL PROGRAMMING DALAM MASALAH PEMILIHAN PROYEK PEMASARAN
}

\section{Zero-One Goal Programming Application in the Selection Problem of Marketing Projects}

\author{
Bib Paruhum Silalahi ${ }^{1 *}$, Silviana Eka Pertiwi $^{2}$, Hidayatul Mayyani ${ }^{3}$, Nur Aliatiningtyas ${ }^{4}$ \\ 1,2,3,4 Departemen Matematika, Fakultas MIPA, Institut Pertanian Bogor \\ Jl. Meranti Bogor 16680, Indonesia \\ e-mail:1*bibparuhum@gmail.com; ${ }^{2}$ silvianaekaprtw@gmail.com; \\ ${ }^{3}$ mayyani_mat15@apps.ipb.ac.id; ${ }^{4}$ nural@apps.ipb.ac.id \\ Corresponding author*
}

\begin{abstract}
Abstrak
Manajemen pemasaran adalah suatu kegiatan untuk merencanakan serta mengorganisasi kegiatan pemasaran agar tercapai tujuan organisasi atau perusahaan secara efektif dan efisien. Masalah muncul bila terdapat beberapa atau banyak proyek berbeda yang dapat diimplementasikan sebagai proyek pemasaran perusahaan. Proyek-proyek ini biasanya dikategorikan oleh beberapa tujuan. Tujuan-tujuan ini dapat saling melengkapi ataupun saling bertentangan. Pada pengoperasiannya, pembuat keputusan akan dituntut untuk memilih dan menentukan proyek yang tepat untuk mencapai target. Dalam tulisan ini dibahas model pemrograman dengan menggunakan pendekatan zero-one goal programming, suatu pemilihan proyek pemasaran untuk memenuhi banyak tujuan dan kendala serta kemudian diberikan contoh implementasinya. Pembahasan dan implementasi mencakup goal programming kategori: nonpreemptive goal programming dan preemptive goal programming.
\end{abstract}

Kata Kunci : Nonpreemptive goal programming, preemptive goal programming, proyek pemasaran,zero-one goal, programming

\begin{abstract}
Marketing management is an activity to plan and organize marketing activities in order to achieve organizational or company goals efficiently and effectively. Problems arise when there are several or many different projects that can be implemented as company marketing projects. These projects are usually categorized by several objectives. These goals can be complementary or contradictory. In operation, decision-makers are required to choose and determine the right project to achieve the target. In this paper, we discuss a programming model using the zero-one goal programming approach, a selection of marketing projects to meet many objectives and constraints, and then give examples of its implementation. Discussion and implementation include goal programming categories: nonpreemptive goal programming and preemptive goal programming.
\end{abstract}

Keywords: Nonpreemptive goal programming, preemptive goal programming, marketing project, zeroone goal, programming 


\section{PENDAHULUAN}

Pemasaran adalah suatu proses yang membuat individu atau kelompok mendapatkan apa yang mereka butuhkan dengan menciptakan, menawarkan, dan mempertukarkan produk yang bernilai kepada pihak lain. Pemasaran juga dapat didefinisikan sebagai segala kegiatan yang menyangkut penyampaian produk/jasa mulai dari produsen sampai konsumen [1]. Manajemen pemasaran adalah suatu usaha untuk merencanakan, mengorganisasi, mengarahkan, mengkoordinir serta mengawasi atau mengendalikan kegiatan pemasaran dalam suatu organisasi agar tercapai tujuan organisasi secara efisien dan efektif [1]. Dalam suatu perusahaan, bagian manajemen pemasaran akan berusaha untuk melakukan pemasaran dengan baik sehingga dapat mencapai target yang diberikan oleh perusahaan tanpa mengabaikan prinsip kepuasan pelanggan.

Masalah muncul ketika terdapat beberapa atau banyak proyek berbeda yang dapat diimplementasikan sebagai proyek pemasaran perusahaan. Proyek-proyek ini biasanya dikategorikan oleh beberapa tujuan. Tujuan-tujuan ini dapat saling melengkapi ataupun saling bertentangan [2]. Pada pengoperasiannya, manajer pemasaran sebagai pembuat keputusan akan dituntut untuk memilih dan menentukan proyek yang tepat untuk mencapai target. Dalam paper ini, akan dibahas mengenai model pemrograman dengan menggunakan pendekatan zero-one goal programming yang membantu dalam menentukan proyek pemasaran yang tepat untuk diimplementasikan oleh perusahaan sesuai dengan tujuan dan kendala yang dimiliki oleh perusahaan serta mengimplementasikannya menggunakan LINGO 18.0.

Goal programming merupakan salah satu bentuk pengembangan untuk menyelesaikan pemrograman linear yang mempunyai fungsi objektif lebih dari satu. Menurut Hillier dan Lieberman [3], pendekatan dasar dari goal programming adalah untuk menetapkan suatu target yang dinyatakan dengan angka tertentu untuk setiap tujuan, merumuskan suatu fungsi tujuan untuk setiap tujuan, dan kemudian mencari penyelesaian yang meminimumkan jumlah deviasi atau penyimpangan dari fungsi-fungsi tujuan terhadap target masing-masing. Goal programming sendiri terdiri dari beberapa komponen yaitu variabel keputusan, variabel deviasi, kendala tujuan, kendala sistem, dan fungsi objektif [4].

Model awal dari sebuah goal programming dapat dinyatakan sebagai:

$$
\min \sum_{i=1}^{P}\left|f_{i}(X)-g_{i}\right|
$$

Kendala $X \in F, F$ adalah himpunan feasible,

dimana $f_{i}(X)=$ fungsi linear dari tujuan ke- $i$ dan $g_{i}=$ target yang ditentukan oleh pembuat keputusan untuk tujuan ke- $i$. Interpretasi dari model ini adalah untuk meminimumkan jumlah nilai absolut dari perbedaan antara nilai target dan nilai yang sesungguhnya dicapai [5].

Dalam persamaan (1), fungsi objektif merupakan fungsi non-linear dimana metode simpleks tidak dapat diterapkan secara langsung. Oleh karena itu persamaan (1) dapat ditransformasikan ke dalam bentuk linear sehingga menjadi tipe khusus dari pemrograman linear. Transformasi ini mendefinisikan variabel baru yaitu $d_{i}^{+}$dan $d_{i}{ }^{-}$dengan:

$$
\begin{aligned}
& d_{i}{ }^{+}=\frac{1}{2}\left\{\left|f_{i}(X)-g_{i}\right|+\left[f_{i}(X)-g_{i}\right]\right\}, \\
& d_{i}{ }^{-}=\frac{1}{2}\left\{\left|f_{i}(X)-g_{i}\right|-\left[f_{i}(X)-g_{i}\right]\right\},
\end{aligned}
$$

$d_{i}{ }^{+}$dan $d_{i}{ }^{-}$secara berturut-turut adalah deviasi positif dan negatif dari target ke-i untuk tujuan ke-i. Setelah menambahkan persamaan (2) dan (3) dapat dilihat bahwa

$$
d_{i}{ }^{+}+d_{i}{ }^{-}=\left|f_{i}(X)-g_{i}\right| .
$$

Oleh karena itu, fungsi objektif di persamaan (1) dapat diganti dengan hubungan linear yang ekuivalen dengan menjumlahkan (2) dan (3). Selanjutnya dengan mengurangi (2) dari (3), diperoleh hubungan sebagai berikut:

$$
f_{i}(X)-g_{i}=d_{i}{ }^{+}-d_{i}{ }^{-}
$$

dengan ${d_{i}}^{+}, d_{i}{ }^{-} \geq 0$. Salah satu ataupun kedua variabel deviasi pasti bernilai 0 atau dengan kata lain $d_{i}{ }^{+}$. $d_{i}{ }^{-}=0$, hal ini dikarenakan dalam suatu tujuan tidak mungkin memiliki deviasi positif dan deviasi negatif secara bersamaan. 
Oleh karena itu diperoleh formulasi linear yang ekuivalen dengan (1) yaitu:

$$
\begin{gathered}
\min z=\sum_{i=1}^{P}\left(d_{i}^{+}+{d_{i}}^{-}\right) \\
\text {kendala } f_{i}(X)-g_{i}=d_{i}^{+}-{d_{i}}^{-}, \\
d_{i}{ }^{+}, d_{i}^{-} \geq 0, i=1,2,3, \ldots, P \\
X \in F, F \text { adalah himpunan feasible. }
\end{gathered}
$$

Menurut Hillier dan Lieberman [3], terdapat tiga tipe tujuan yang mungkin digunakan dalam penyelesaian permasalahan goal programming, yaitu:

1. Meminimumkan $d_{i}{ }^{-}$

Hal ini dilakukan untuk meminimumkan hasil yang berada di bawah target.

2. Meminimumkan $d_{i}^{+}$

Hal ini dilakukan untuk meminimumkan hasil yang berada di atas target.

3. Meminimumkan $d_{i}^{+}+d_{i}^{-}$

Hal ini dilakukan untuk meminimumkan hasil yang berada di bawah dan di atas target. Selanjutnya Hillier dan Lieberman [3] menyatakan bahwa goal programming dapat dikategorikan berdasarkan perbandingan kepentingan dari tujuan-tujuan yang dimiliki. Kategori pertama, nonpreemptive goal programming, adalah saat semua tujuan memiliki kepentingan yang kurang lebih sebanding. Sedangkan pada kategori kedua, preemptive goal programming, terdapat hirarki tingkat prioritas atas tujuan-tujuan yang dimiliki. Dalam kasus nonpreemptive goal programming, semua tujuan memiliki perbandingan tingkat kepentingan yang sangat kecil ataupun tidak ada sama sekali. Dengan demikian, kasus ini tidak memerlukan adanya prioritas dalam penyelesaiannya.

Kasus nonpreemptive goal programming dapat diselesaikan dengan menggunakan metode simpleks. Hal ini dapat dilakukan karena koefisien dari tiap fungsi objektif merupakan nilai numerik yang telah diketahui.Sementara itu, dalam kasus preemptive goal programming terdapat hirarki tingkat prioritas atas tujuan-tujuan yang dimiliki mulai dari yang terpenting hingga yang kurang penting. Kasus ini terjadi saat terdapat satu atau lebih tujuan yang jauh lebih penting dan harus diutamakan dari tujuan yang lain. Salah satu metode untuk menyelesaikan permasalahan preemptive goal programming adalah dengan menyelesaikan serangkaian model pemrograman linear. Metode ini disebut dengan sequential procedure (prosedur sekuensial). Tiap tahap pada prosedur sekuensial hanya memuat tujuan pada tingkat prioritas yang sama mulai dari prioritas pertama hingga akhir. Hasil yang didapatkan kemudian digunakan sebagai variabel tetap di tahap selanjutnya [3].

Zero-one goal programming merupakan bentuk pengembangan dari model umum goal programming. Model ini merupakan model yang sederhana dan mudah dimengerti sehingga menjadi salah satu teknik yang mulai banyak digunakan untuk menyelesaikan banyak permasalahan. Menurut Liao [6], zero-one goal programming adalah sebuah pendekatan pemrograman matematika untuk menetapkan nilai optimal bagi sebuah himpunan variabel dalam permasalahan dimana terdapat beberapa tujuan serta terdapat tujuan yang bertentangan. Permasalahan zero-one goal programming memiliki bentuk umum:

$$
\begin{aligned}
\min z & =\sum_{i=1}^{n}\left(d_{i}{ }^{+}+d_{i}{ }^{-}\right) \\
\text {Kendala } \quad \sum_{i=1}^{n} c_{i j} y_{j}-g_{i} & =d_{i}^{+}-d_{i}{ }^{-}, i=1,2, \ldots, n, \\
y_{j} & =0,1, j=1,2, \ldots, n,
\end{aligned}
$$

Dengan $\quad g_{i}=$ target dari tujuan ke- $i$;

$d_{i}^{+}=$simpangan nilai di atas pencapaian (deviasi positif) dari tujan ke- $i$;

$d_{i}{ }^{-}=$simpangan nilai di bawah pencapaian (deviasi negatif) dari tujuan ke- $i$;

$y_{j}=$ variabel biner

$c_{i j}=$ kontribusi dari proyek ke- $j$ terhadap tujuan ke- $i$ 
Goal programming adalah bagian dari matematika untuk mencari nilai optimum, yang dikenal dengan nama optimisasi. Optimisasi adalah cabang ilmu matematika yang mempelajari teknik-teknik pencarian nilai maksimum atau minimum dari suatu problem. Terdapat banyak penelitian tentang optimisasi, beberapa diantaranya: optimisasi menggunakan algoritme sweep dan particle swarm optimization [7], optimisasi menggunakan algoritme koloni semut (ant colony algorithm) [8], optimisasi menggunakan interior-point method [9,10], optimisasi pendekatan Newton [11], metode kombinasi untuk menyelesaikan masalah optimisasi [12], penelitian dalam bidang transportasi [13-17] .

Berikut ini adalah contoh permasalahan zero-one goal programming dan penyelesaiannya. Sebuah perusahaan akan memilih rencana produksi terbaik dari tiga rancangan yang ada untuk produk terbarunya. Perusahaan ini memiliki dua tujuan yang ingin dicapai yaitu memaksimumkan pendapatan dan meminimumkan pengeluaran (Tabel 1).

Tabel 1. Tujuan, kontribusi produksi dan target perusahaan

\begin{tabular}{ccccc}
\multirow{2}{*}{ Tujuan } & \multicolumn{3}{c}{ Kontribusi (juta rupiah) rencana produksi ke- } & \multirow{2}{*}{ Target (juta rupiah) } \\
\cline { 2 - 4 } & 1 & 2 & 3 & \\
\hline Pendapatan & 21 & 15 & 16 & $\geq 30$ \\
\hline Pengeluaran & 3 & 5 & 4 & $\leq 10$ \\
\hline
\end{tabular}

Apabila perusahaan menentukan bahwa tujuan untuk memaksimumkan pendapatan jauh lebih penting dari tujuan meminimumkan pengeluaran maka model goal programming ini dapat diselesaikan dengan mencari $d_{1}{ }^{-}$terlebih dahulu yaitu dengan formulasi:

$$
\begin{gathered}
\text { Min } d_{1}{ }^{-} \\
\text {kendala } 21 y_{1}+15 y_{2}+16 y_{3}-30=d_{1}{ }^{+}-d_{1}{ }^{-}, \\
3 y_{1}+5 y_{2}+4 y_{3}-10=d_{2}{ }^{+}-d_{2}{ }^{-} \\
y_{j}=0,1, j=1,2,3 .
\end{gathered}
$$

Berdasarkan keluaran LINGO didapatkan nilai $d_{1}{ }^{-}$yaitu 0 . Hasil ini kemudian digunakan sebagai variabel tetap dalam kendala untuk menyelesaikan tahap kedua yaitu tujuan untuk meminimumkan pengeluaran. Formulasi tahap kedua:

$$
\begin{aligned}
& \operatorname{Min}{d_{2}}^{+} \\
\text {kendala } 21 y_{1} & +15 y_{2}+16 y_{3}-30=d_{1}{ }^{+}-d_{1}{ }^{-}, \\
3 y_{1} & +5 y_{2}+4 y_{3}-10=d_{2}{ }^{+}-d_{2}{ }^{-} \\
d_{1}{ }^{-} & =0 \\
y_{j} & =0,1, j=1,2,3 .
\end{aligned}
$$

Penyelesaian LINGO akan menunjukan bahwa rencana yang terpilih adalah rencana produksi kedua dan ketiga dengan total pendapatan sebesar Rp31.000.000 dan total pengeluaran sebesar Rp9.000.000.

Apabila urutan prioritas tujuan yang dimiliki perusahaan ditukar, yaitu tujuan untuk meminimumkan pengeluaran jauh lebih penting dari tujuan memaksimumkan pendapatan maka tahap penyelesaian model goal programming ini juga dapat ditukar urutannya. Tahap pertama yang dilakukan untuk menyelesaikan kasus ini adalah dengan mencari nilai $d_{2}{ }^{+}$yang kemudian dilanjutkan dengan mencari nilai $d_{1}{ }^{-}$. Penyelesaian LINGO akan menunjukan bahwa rencana yang terpilih adalah rencana produksi pertama dan ketiga dengan total pendapatan sebesar Rp37.000.000 dan total pengeluaran sebesar Rp7.000.000.

Sementara itu, apabila perusahaan menentukan tidak ada perbedaan tingkat prioritas dari tujuan-tujuan yang ingin dicapai, maka penyelesaian model dapat dilakukan dengan mencari nilai $d_{1}{ }^{-}$dan $d_{2}{ }^{+}$secara bersamaan. Formulasi untuk kasus ini dapat dituliskan ke dalam:

$$
\begin{gathered}
\text { Min } d_{1}{ }^{-}+d_{2}{ }^{+} \\
\text {kendala } 21 y_{1}+15 y_{2}+16 y_{3}-30=d_{1}{ }^{+}-d_{1}{ }^{-} \\
3 y_{1}+5 y_{2}+4 y_{3}-10=d_{2}{ }^{+}-d_{2}{ }^{-} \\
y_{j}=0,1, \quad j=1,2,3
\end{gathered}
$$


Hasil dari penyelesaian LINGO menunjukan bahwa himpunan rencana yang terpilih sama dengan hasil pada kasus pertama yaitu rencana produksi kedua dan ketiga dengan total pendapatan sebesar Rp31.000.000 dan total pengeluaran sebesar Rp9.000.000.

\section{METODE PENELITIAN}

Diasumsikan sebuah perusahaan dalam menjalankan manajemen pemasaran ingin memilih proyek pemasaran baru untuk diterapkan. Perusahaan tersebut mempunyai beberapa pilihan proyek yang tersedia. Manajer pemasaran dari perusahaan tersebut harus menentukan proyek mana saja yang paling sesuai dan dapat memenuhi tujuan-tujuan dari perusahaan. Berikut adalah beberapa tujuan yang ingin dicapai oleh perusahaan:

1. Memaksimumkan pendapatan

Salah satu tujuan utama yang ingin dicapai semua perusahaan pastilah berhubungan dengan memaksimumkan pendapatan yang akan dicapai. Tujuan ini merepresentasikan total pendapatan yang akan diperoleh dari proyek-proyek yang diimplementasikan dimana pengimplementasian setiap proyek diketahui memiliki kontribusi pendapatan masing-masing dalam mencapai target pendapatan yang diinginkan. Dari pihak perusahaan sendiri, akan diberikan nilai target/patokan pendapatan yang diharapkan dapat dicapai dari hasil pengimplementasian proyek yang telah terpilih.

2. Meminimumkan biaya penggunaan hardware (material) dan software (digital)

Penggunaan hardware (material) dan software (digital) merupakan salah satu faktor utama di bidang pemasaran. Keduanya sangatlah berperan penting terutama saat proses riset pasar dan promosi. Dalam proses ini terdapat serangkaian proses pengumpulkan informasi, design, koleksi, analisa dan pelaporan data secara sistematis. Oleh karena itu, biaya ini biasanya dianggarkan oleh perusahaan. Berkebalikan dengan tujuan keuntungan, tujuan yang akan dicapai untuk biaya penggunaan hardware adalah untuk meminimumkannya.

3. Meminimumkan biaya pekerja

Untuk melakukan suatu proyek pemasaran sangatlah diperlukan untuk memperhatihan pula masalah tenaga kerja yang diperlukan. Semakin banyak tenaga kerja yang dibutuhkan dalam suatu proyek maka akan semakin besar biaya yang harus dikeluarkan untuk upah tenaga kerja tersebut. Oleh karena itu, tujuan selanjutnya adalah untuk meminimumkan tenaga kerja yang diperlukan.

4. Meminimumkan biaya tambahan lain

Proses pengerjaan proyek dapat bersifat tak tentu. Tak jarang dalam pengerjaannya diperlukan biaya tambahan. Biaya ini biasa diperlukan untuk transportasi, konsultasi dan lainnya. Oleh karena itu, diperlukan tujuan untuk meminimumkan biaya tambahan yang sekiranya akan diperlukan.

5. Tujuan yang berhubungan dengan tingkat preferensi

Tujuan kegiatan pemasaran biasanya dioperasikan melalui kebutuhan dan informasi yang dibutuhkan oleh peserta kegiatan pemasaran serta pengambil keputusan. Namun selain kedua hal tersebut preferensi juga merupakan hal yang tidak bisa diabaikan. Hal ini membuat adanya fungsi objektif berdasarkan preferensi. Setiap tingkatan preferensi dinilai dengan rentang 1-10, dengan 1 mengindikasikan tingkat preferensi yang tinggi dan 10 mengindikasikan tingkat preferensi yang rendah.

6. Meminimumkan waktu penyelesaian dan pelatihan proyek

Kedua tujuan ini diikut sertakan agar meminimumkan waktu yang dibutuhkan untuk menyelesaikan proyek yang akan diimplementasikan. Selain itu, pembuat keputusan juga menyadari pentingnya waktu pelatihan sebelum proyek benar-benar diimplementasikan. Oleh karena itu, diperlukan juga untuk meminimumkan waktu pelatihan dengan tetap memperhatikan kesiapan pengimplementasian proyek.

7. Tujuan yang berhubungan dengan resiko

Dalam pengoperasiannya tak jarang suatu proyek mengalami kegagalan. Hal ini dapat terjadi akibat kesalahan teknik ataupun permasalahan menyangkut manajemen. Oleh karena itu, penting untuk tidak mengabaikan tujuan untuk meminimumkan resiko dari pengimplementasian proyek. Banyak faktor yang dapat digunakan untuk mengukur resiko. Termasuk di dalamnya adalah pengalaman dari pemimpin proyek, ukuran dari tim proyek, komitmen dan sebagainya. Tingkat resiko dinilai dengan rentang 1-10, dengan 1 merepresentasikan tingkat resiko paling rendah. 
Sebagai tambahan, diasumsikan dari semua pilihan proyek yang ada terdapat proyek yang harus diterapkan berdasarkan peraturan perusahaan. Dengan demikian dalam formulasi masalah nantinya perlu juga disertakan kendala proyek yang harus diterapkan. Seperti yang telah dibahas, permasalahan ini mempunyai banyak tujuan yang ingin dicapai. Oleh karena itu, permasalahan akan diformulasikan ke dalam model 0-1 goal programming dengan mengubah tujuan-tujuan ini menjadi kendala yang diperlukan. Sebagai hasil, akan diketahui proyek-proyek mana saja yang terpilih serta nilai deviasi minimum yang didapatkan jika mengimplementasikan proyek-proyek terpilih ini.

\section{Himpunan dan Indeks}

$P=$ Himpunan proyek pemasaran, yaitu $P=1,2, \ldots, n$ dengan indeks $j$.

$G=$ Himpunan tujuan/target perusahaan, yaitu $G=1,2, \ldots, m$ dengan indeks $i$.

\section{Parameter}

$c_{i j}=$ Nilai dugaan kontribusi proyek ke- $j$ untuk target atau tujuan ke- $i$.

$g_{i}=$ Nilai target yang telah ditentukan untuk tujuan ke- $i$.

\section{Variabel Keputusan}

$$
\begin{aligned}
y_{j}= & \begin{cases}1, \text { jika proyek ke } j & \text { terpilih } \\
0, & \text { selainnya }\end{cases} \\
& j=1,2, \ldots, n .
\end{aligned}
$$

\section{Variabel Deviasi}

$d_{i}{ }^{+}=$Deviasi positif untuk kendala yang berhubungan dengan tujuan ke- $i$.

$d_{i}{ }^{-}=$Deviasi negatif untuk kendala yang berhubungan dengan tujuan ke- $i$.

\section{Kendala}

1. Kendala untuk memenuhi tujuan yang berhubungan dengan pendapatan

$$
\sum_{j=1}^{n} c_{1 j} y_{j}-g_{1}=d_{1}{ }^{+}-d_{1}{ }^{-} .
$$

2. Kendala untuk memenuhi tujuan yang berhubungan dengan biaya penggunaan software

$$
\sum_{j=1}^{n} c_{2 j} y_{j}-g_{2}=d_{2}{ }^{+}-d_{2}{ }^{-} \text {. }
$$

3. Kendala untuk memenuhi tujuan yang berhubungan dengan biaya penggunaan hardware

$$
\sum_{j=1}^{n} c_{3 j} y_{j}-g_{3}=d_{3}{ }^{+}-d_{3}{ }^{-} \text {. }
$$

4. Kendala untuk memenuhi tujuan yang berhubungan dengan pekerja

$$
\sum_{j=1}^{n} c_{4 j} y_{j}-g_{4}=d_{4}{ }^{+}-d_{4}{ }^{-} \text {. }
$$

5. Kendala untuk memenuhi tujuan yang berhubungan dengan biaya tambahan lain

$$
\sum_{j=1}^{n} c_{5 j} y_{j}-g_{5}=d_{5}{ }^{+}-d_{5}{ }^{-} \text {. }
$$

6. Kendala untuk memenuhi tujuan yang berhubungan dengan preferensi

$$
\sum_{j=1}^{n} c_{6 j} y_{j}-g_{6}=d_{6}{ }^{+}-d_{6}{ }^{-}
$$

7. Kendala untuk memenuhi tujuan yang berhubungan dengan waktu penyelesaian proyek

$$
\sum_{j=1}^{n} c_{7 j} y_{j}-g_{7}=d_{7}{ }^{+}-d_{7}{ }^{-} \text {. }
$$

8. Kendala untuk memenuhi tujuan yang berhubungan dengan waktu pelatihan proyek 


$$
\sum_{j=1}^{n} c_{8 j} y_{j}-g_{8}=d_{8}{ }^{+}+d_{8}{ }^{-}
$$

9. Kendala untuk memenuhi tujuan yang berhubungan dengan resiko

$$
\sum_{j=1}^{n} c_{9 j} y_{j}-g_{9}=d_{9}{ }^{+}+d_{9}{ }^{-} \text {. }
$$

10. Kendala proyek yang harus diterapkan

$$
y_{j}=1, j \in L, L \subset\{1,2, \ldots, n\} \text {. }
$$

\section{Fungsi Objektif}

Fungsi objektif dari permasalahan ini yaitu untuk meminimumkan jumlah dari total deviasi positif dan negatif yang berhubungan dengan kendala-kendala di atas dan dapat dituliskan ke dalam persamaan:

$$
\min z=d_{1}{ }^{-}+\sum_{i=2}^{9} d_{i}^{+}
$$

\section{HASIL DAN PEMBAHASAN}

\subsection{Ilustrasi}

Misalkan dalam suatu perusahaan akan dipilih proyek-proyek pemasaran. Terdapat 20 proposal proyek yang telah diajukan untuk dapat diimplementasikan. Proyek-proyek ini diharapkan dapat memenuhi tujuantujuan dari perusahaan. Data nilai dugaan dari pendapatan yang akan diperoleh tiap proyek disajikan dalam Tabel 2 sebagai berikut:

Tabel 2. Nilai dugaan pendapatan tiap proyek

\begin{tabular}{rr}
\hline Proyek & Pendapatan (Rp000) \\
\hline 1 & 7503 \\
\hline 2 & 12297 \\
\hline 3 & 10216 \\
\hline 4 & 6051 \\
\hline 5 & 11479 \\
\hline 6 & 5617 \\
\hline 7 & 12223 \\
\hline 8 & 8547 \\
\hline 9 & 13146 \\
\hline 10 & 13257 \\
\hline
\end{tabular}

\begin{tabular}{rr}
\hline Proyek & Pendapatan (Rp000) \\
\hline 11 & 11358 \\
\hline 12 & 6285 \\
\hline 13 & 10620 \\
\hline 14 & 10510 \\
\hline 15 & 8869 \\
\hline 16 & 11808 \\
\hline 17 & 12295 \\
\hline 18 & 14724 \\
\hline 19 & 6348 \\
\hline 20 & 7123 \\
\hline
\end{tabular}

Selain pendapatan, diberikan juga nilai dugaan bagi biaya-biaya yang perlu dikeluarkan untuk mengimplementasikan tiap proyek. Biaya-biaya ini terdiri dari biaya penggunaan software dan hardware, upah pekerja serta biaya tambahan. Nilai-nilai ini disajikan dalam Tabel 3. 


\begin{tabular}{ccccc}
\hline Proyek & $\begin{array}{c}\text { Biaya } \\
\text { Software (Rp000) }\end{array}$ & $\begin{array}{c}\text { Biaya } \\
\text { Hardware (Rp000) }\end{array}$ & $\begin{array}{c}\text { Biaya } \\
\text { Pekerja (Rp000) }\end{array}$ & $\begin{array}{c}\text { Biaya } \\
\text { tambahan (Rp000) }\end{array}$ \\
\hline 1 & 1602 & 1022 & 2081 & 65 \\
\hline 2 & 464 & 1993 & 6259 & 645 \\
\hline 3 & 2862 & 2053 & 4687 & 361 \\
\hline 4 & 2415 & 3181 & 5100 & 280 \\
\hline 5 & 775 & 3081 & 6797 & 79 \\
\hline 6 & 2399 & 3013 & 1029 & 599 \\
\hline 7 & 1875 & 3384 & 3078 & 300 \\
\hline 8 & 1344 & 4793 & 3304 & 60 \\
\hline 9 & 1509 & 3266 & 1085 & 237 \\
\hline 10 & 1519 & 1093 & 2944 & 513 \\
\hline 11 & 2247 & 2647 & 606 & 266 \\
\hline 12 & 2482 & 2376 & 6387 & 656 \\
\hline 13 & 2637 & 1317 & 7448 & 570 \\
\hline 14 & 2731 & 911 & 4172 & 331 \\
\hline 15 & 450 & 2443 & 8237 & 528 \\
\hline 16 & 1953 & 668 & 3361 & 207 \\
\hline 17 & 913 & 4170 & 8875 & 536 \\
\hline 18 & 2058 & 4076 & 5679 & 461 \\
\hline 19 & 1805 & 732 & 6422 & 47 \\
\hline 20 & 2967 & 1775 & 3639 & 45 \\
\hline
\end{tabular}

Sementara itu, Tabel 4 menyajikan nilai preferensi yang diberikan petinggi perusahaan dan pengambil keputusan, dugaan waktu penyelesaian dan pelatihan serta tingkat resiko dari tiap proyek.

Tabel 4. Nilai preferensi, resiko dan dugaan waktu yang diperlukan tiap proyek Proyek Preferensi Waktu penyelesaian Waktu pelatihan Resiko

\begin{tabular}{ccccc}
\hline 1 & 6 & 25 & 3 & 2 \\
\hline 2 & 8 & 19 & 7 & 1 \\
\hline 3 & 3 & 16 & 1 & 3 \\
\hline 4 & 1 & 26 & 5 & 3 \\
\hline 5 & 7 & 24 & 6 & 4 \\
\hline 6 & 2 & 27 & 5 & 5 \\
\hline 7 & 7 & 19 & 2 & 3 \\
\hline 8 & 5 & 30 & 9 & 2 \\
\hline 9 & 3 & 22 & 4 & 1 \\
\hline 10 & 7 & 27 & 4 & 3 \\
\hline 11 & 1 & 28 & 2 & 3 \\
\hline 12 & 6 & 18 & 9 & 1 \\
\hline 13 & 1 & 10 & 9 & 1 \\
\hline 14 & 5 & 12 & 3 & 1 \\
\hline 15 & 2 & 17 & 9 & 4 \\
\hline 16 & 1 & 11 & 6 & 5 \\
\hline 17 & 5 & 19 & 10 & 2 \\
\hline 18 & 1 & 25 & 6 & 3 \\
\hline 19 & 5 & 12 & 5 & 3 \\
\hline 20 & 4 & 16 & 10 & 5 \\
\hline & & & &
\end{tabular}


Perusahaan juga diketahui telah memiliki beberapa pilihan proyek untuk diterapkan. Sifat wajib atau tidaknya suatu proyek untuk diterapkan disajikan dalam Tabel 5.

Tabel 5. Sifat proyek

\begin{tabular}{cc}
\hline Proyek & Wajib diterapkan \\
\hline 1 & Tidak \\
\hline 2 & Tidak \\
\hline 3 & Tidak \\
\hline 4 & Ya \\
\hline 5 & Tidak \\
\hline 6 & Tidak \\
\hline 7 & Tidak \\
\hline 8 & Tidak \\
\hline 9 & Tidak \\
\hline 10 & Tidak \\
\hline 11 & Tidak \\
\hline 12 & Tidak \\
\hline 13 & Tidak \\
\hline 14 & Ya \\
\hline 15 & Tidak \\
\hline 16 & Tidak \\
\hline 17 & Tidak \\
\hline 18 & Tidak \\
\hline 19 & Tidak \\
\hline 20 & Tidak \\
\hline
\end{tabular}

Pihak perusahaan juga telah menentukan nilai estimasi total pendapatan yang diinginkan untuk tiap tujuan seperti yang disajikan dalam Tabel 6 .

Tabel 6. Nilai estimasi target perusahaan

\begin{tabular}{rr}
\hline Tujuan & Target (Rp000) \\
\hline 1 & 100000 \\
\hline 2 & 16000 \\
\hline 3 & 25000 \\
\hline 4 & 30000 \\
\hline 5 & 3000 \\
\hline 6 & 0 \\
\hline 7 & 0 \\
\hline 8 & 0 \\
\hline 9 & 0
\end{tabular}

Model dari permasalahan ini diselesaikan dengan menggunakan bantuan software LINGO 18.0. Dari keluaran software, dapat dilihat bahwa solusi optimal untuk memenuhi semua tujuan dari perusahaan dapat dicapai dengan hanya memilih beberapa proyek saja. Untuk ilustrasi, dilakukan tiga kali simulasi untuk membandingkan hasil yang didapat.

\subsection{Simulasi 1}

Pada simulasi pertama, diasumsikan bahwa tidak ada tingkatan prioritas dari semua tujuan yang akan dicapai. Dari total dari 20 proposal proyek, terdapat 9 proyek yang terpilih yaitu proyek ke $2,4,7,8,9,10$, 
11, 14 dan 16. Didapatkan masing-masing deviasi positif dan negatif untuk tujuan-tujuan yang ada seperti yang tertera dalam Tabel 7.

Tabel 7. Deviasi positif dan negatif tiap tujuan untuk simulasi pertama

\begin{tabular}{rrr}
\hline Tujuan ke- & Deviasi Positif & Deviasi negatif \\
\hline 1 & 0 & 803 \\
\hline 2 & 57 & 0 \\
\hline 3 & 0 & 3064 \\
\hline 4 & 0 & 91 \\
\hline 5 & 0 & 161 \\
\hline 6 & 38 & 0 \\
\hline 7 & 194 & 0 \\
\hline 8 & 42 & 0 \\
\hline 9 & 22 & 0 \\
\hline
\end{tabular}

Oleh karena itu, dengan mengimplementasikan proyek-proyek terpilih maka akan dicapai total pendapatan sebesar Rp99.197.000. Sementara total biaya yang perlu dikeluarkan dalam pengimplementasian proyek-proyek ini adalah Rp70.741.000 dengan rincian: Rp16.057.000 untuk biaya penggunaan software, Rp21.936.000 untuk biaya penggunaan hardware, Rp29.909.000untuk biaya pekerja serta Rp2.839.000 untuk biaya tambahan lain. Apabila diasumsikan bahwa dalam satu periode waktu hanya dapat diimplementasikan satu proyek maka total waktu untuk menyelesaikan semua proyek terpilih yaitu 194 hari dan total waktu pelatihan yaitu 42 hari. Jumlah nilai preferensi dan tingkat resiko yang didapat dari simulasi ini yaitu 38 dan 22 .

\subsection{Simulasi 2}

Pada simulasi kedua, diasumsikan bahwa terdapat tingkatan prioritas untuk setiap tujuan. Pembuat keputusan menginginkan adanya analisis lebih lanjut terhadap proyek-proyek terpilih jika terdapat perbedaan tingkat prioritas pada tujuan khususnya untuk tujuan pendapatan dan penggunaan biaya. Oleh karena itu, pada simulasi kedua dibuatlah urutan prioritas dengan memandang pendapatan sebagai tujuan yang paling penting, total penggunaan biaya pada prioritas kedua, kemudian total waktu yang diperlukan, tingkat resiko dan preferensi pada urutan prioritas ketiga hingga kelima.

Setelah dilakukan proses komputasi, dapat dilihat bahwa tetap ada 9 proyek yang terpilih. Namun, terdapat perbedaan proyek terpilih antara simulasi kedua ini dengan proyek terpilih pada simulasi pertama. Pada simulasi kedua, himpunan proyek yang terpilih terdiri dari proyek ke1, 2, 4, 7, 9, 10, 11, 14 dan 18. Masing-masing deviasi yang didapatkan untuk tiap tujuan pada simulasi ini diberikan pada Tabel 8.

Tabel 8. Deviasi positif dan negatif tiap tujuan untuk simulasi kedua

\begin{tabular}{rrr} 
Tujuan ke- & Deviasi Positif & Deviasi negatif \\
\hline 1 & 1069 & 0 \\
\hline 2 & 420 & 0 \\
\hline 3 & 0 & 3427 \\
\hline 4 & 1004 & 0 \\
\hline 5 & 98 & 0 \\
\hline 6 & 39 & 0 \\
\hline 7 & 203 & 0 \\
\hline 8 & 36 & 0 \\
\hline 9 & 20 & 0
\end{tabular}

Dengan mengimplementasikan himpunan proyek terpilih pada simulasi 2 maka akan dicapai total pendapatan sebesar Rp101.069.000. Sementara itu, total biaya yang perlu dikeluarkan dalam pengimplementasian proyek-proyek ini adalah Rp72.095.000 dengan rincian Rp16.420.000 untuk biaya penggunaan software, Rp21.573.000 untuk biaya penggunaan hardware, Rp31.004.000 untuk biaya pekerja serta Rp3.098.000 untuk biaya tambahan lain. Apabila asumsi untuk waktu pelatihan dan penyelesaian proyek pada simulasi pertama berlaku untuk semua simulasi, maka total waktu untuk menyelesaikan semua proyek 
terpilih yaitu 203 hari dan total waktu pelatihan yaitu 36 hari. Jumlah nilai preferensi dan tingkat resiko yang didapat dari simulasi ini yaitu 39 dan 20.

\subsection{Simulasi 3}

Selanjutnya, untuk simulasi ketiga dilakukan komputasi dengan urutan prioritas total penggunaan biaya, keuntungan, total waktu yang diperlukan, tingkat resiko dan preferensi secara berturut-turut. Pada simulasi ini himpunan proyek terpilih terdiri dari 9 proyek yaitu proyek ke 1, 2, 4, 7, 8, 9, 10, 11, dan 14 . Deviasi positif dan negatif yang didapatkan untuk tiap tujuan pada simulasi ini disajikan pada Tabel 9.

Tabel 9. Deviasi positif dan negatif tiap tujuan untuk simulasi ketiga

\begin{tabular}{rrr}
\hline Tujuan ke- & Deviasi Positif & Deviasi negatif \\
\hline 1 & 0 & 5108 \\
\hline 2 & 0 & 294 \\
\hline 3 & 0 & 2710 \\
\hline 4 & 0 & 1371 \\
\hline 5 & 0 & 303 \\
\hline 6 & 43 & 0 \\
\hline 7 & 208 & 0 \\
\hline 8 & 39 & 0 \\
\hline 9 & 19 & 0 \\
\hline & &
\end{tabular}

Dengan mengimplementasikan himpunan proyek terpilih pada simulasi 3 total pendapatan yang akan dicapai yaitu sebesar Rp94.892.000. Sementara itu, total biaya yang perlu dikeluarkan dalam pengimplementasian proyek-proyek ini adalah Rp69.322.000 dengan rincian sebagai berikut: Rp15.706.000 untuk biaya penggunaan software, Rp22.290.000 untuk biaya penggunaan hardware, Rp28.629.000 untuk biaya pekerja serta Rp2.697.000 untuk biaya tambahan lain. Total waktu untuk menyelesaikan semua proyek terpilih dan total waktu pelatihan pada simulasi tiga secara berturut-turut yaitu 208 hari dan 36 hari. Jumlah nilai preferensi dan tingkat resiko yang didapat dari simulasi ini yaitu 43 dan 19.

Pencapaian yang didapatkan oleh himpunan proyek terpilih pada ketiga simulasi disajikan pada Tabel 10 agar lebih mudah untuk melihat perbandingan hasil dari ketiganya.

Tabel 10. Hasil pencapaian proyek terpilih dari ketiga simulasi

\begin{tabular}{lrrr}
\hline Simulasi & 1 & 2 & 3 \\
\hline Pendapatan & Rp99.197.000 & Rp101.069.000 & Rp94.892.000 \\
\hline Total Pengeluaran & Rp70.741.000 & Rp72.095.000 & Rp69.322.000 \\
\hline Waktu Penyelesaian & 194 & 203 & 208 \\
\hline Waktu Pelatihan & 42 & 36 & 39 \\
\hline Preferensi & 38 & 39 & 43 \\
\hline Resiko & 22 & 20 & 19 \\
\hline
\end{tabular}

Dapat dilihat dari hasil pengimplementasian model bahwa saat tujuan memaksimumkan pendapatan dipandang sebagai prioritas pertama, tercapai keuntungan maksimum dari ketiga simulasi. Pencapaian keuntungan ini juga telah melebihi target dari perusahaan. Namun seiring dengan naiknya keuntungan, total biaya yang diperlukan juga naik dan melebihi anggaran yang dapat disediakan perusahaan. Di lain sisi, saat tujuan total penggunaan biaya dipandang sebagai prioritas pertama, total biaya yang dibutuhkan akan menurun hingga dapat terpenuhi oleh anggaran perusahaan. Tingkat resiko pengimplementasian proyekproyek terpilih dari simulasi ketiga ini juga paling minimal diantara ketiganya. Namun total pendapatan yang diperoleh juga menurun cukup jauh di bawah target perusahaan. Selain itu, seiring turunnya biaya, faktor lain seperti waktu penyelesaian dan pelatihan serta preferensi juga ikut menurun. 


\section{KESIMPULAN}

Pemilihan proyek pemasaran untuk memenuhi banyak tujuan dan kendala dapat dilakukan dengan menggunakan metode zero-one goal programming. Kemampuannya untuk menguji dan mengukur sensitifitas terhadap perubahan prioritas berbagai tujuan dalam satu model dapat menjadi alat bantu yang berguna bagi pembuat keputusan. Pada penelitian ini telah dibentuk suatu formulasi model masalah pemilihan proyek pemasaran. Model ini mempunyai fungsi tujuan untuk meminimumkan total deviasi yang berhubungan dengan tujuan-tujuan yang dimiliki. Tujuan yang digunakan dalam model di penelitian ini berhubungan dengan pendapatan, biaya penggunaan software dan hardware, biaya pekerja, biaya tambahan lain, preferensi, waktu pelatihan dan penyelesaian proyek, serta resiko. Dilakukan tiga kali simulasi yang dibedakan berdasarkan tingkat prioritas dari tujuan-tujuan yang ada. Dari hasil keluaran, dapat dilihat proyekproyek yang terpilih serta deviasi dari tiap tujuan.

\section{DAFTAR PUSTAKA}

[1] Shinta, Manajemen Pemasaran. Malang (ID): Brawijaya Univ Pr, 2011.

[2] M.A. Badir, D. Davis, D. Davis, “A Comprehensive 0-1 Programming Model for Project Selection,"International Journal of Project Management,vol. 19, pp. 243-252, 2001.

[3] F.S. Hillier, J.G. Lieberman, Introduction to Operations Research $9^{\text {th }}$ ed. Mc Graw Hill Companies, Inc. 2010.

[4] R.A. Sarker, C.S. Newton, Optimization Modelling : A Practical Approach. New York (US): CRC Pr, 2008.

[5] S.S. Valunjkar, "Goal Programming (A Learning Material)", 2015 [Online] [diunduh pada 12 Feb 2020]. Tersedia pada http://www.researchgate.net/publication/276277136_Goal_Programming_A_Learning_Material.

[6] C.N. Liao, "A Zero-One Goal Programming Model for Marketing Project Selection,"Journal of China Institute of Technology, vol. 40(6), pp. 77-88, 2009.

[7] B.P. Silalahi, K. Fatihin, P.T. Supriyo, and S. Guritman, 2020. "Algoritme Sweep dan Particle Swarm Optimization dalam Optimisasi Rute Kendaraan dengan Kapasitas," Jurnal Matematika Integratif, vol. 16(1), pp. 29-40, 2020.

[8] B.P. Silalahi, N. Fathiah, P.T. Supriyo, "Use of Ant Colony Optimization Algorithm for Determining Traveling Salesman Problem Routes," Jurnal Matematika "MANTIK", vol. 5(2), pp. 100-111, 2019.

[9] B.P. Silalahi, "Evaluation of interior-point method in Scilab," IOP Conference Series: Earth and Environmental Science, vol. 299, number 1, 012040, doi:10.1088/1755-1315/299/1/012040, 2019.

[10] B.P. Silalahi, F. Bukhari, A. Aman, E. Khatizah, N.A. Fahlevi, "Comparison of Interior Point Method Execution Time in Solving Linear Optimization Problems using Mathematica and Scilab," International Journal of Statistics \& Economics, vol. 20(40), pp. 74-81, 2019.

[11] B.P. Silalahi, Siswandi, A. Aman, "Tinjauan terhadap Metode Pengoptimuman Pendekatan Newton," Journal of Mathematics and Its Applications, vol. 17(2), pp. 141-155, 2018.

[12] B.P. Silalahi, R. Laila, I.S. Sitanggang, "A combination method for solving nonlinear equations," IOP Conference Series: Materials Science and Engineering, 166(1): 012011, 2017

[13] M.M.A Kautsar, B.P. Silalahi, S. Guritman, "Paradox in a d-dimensional transportation problem," International Journal of Pure and Applied Mathematics, vol. 118 (3), pp. 547-557, 2018.

[14] D. Lalang, B.P. Silalahi, F. Bukhari, "Vehicle Routing Problem TIME Windows dengan Pengemudi Sesekali," Journal of Mathematics and Its Applications, vol. 17(2), pp. 87-99, 2018

[15] S.R.M. Making, B.P. Silalahi, F. Bukhari, "Multi depot vehicle routing problem dengan pengemudi sesekali," Jurnal Matematika dan Aplikasinya, vol. 17(1), pp. 75-86, 2018

[16] H. Mayyani, B.P. Silalahi, A. Aman, "Frequency determination of bus rapid transit (BRT) applied on service system of trans mataram metro bus to minimize the operational cost," International Journal of Engineering and Management Research (IJEMR), vol. 7(6), pp. 134-140, 2017.

[17] F.D. Wihartiko, A. Buono, B.P. Silalahi, "Integer programming model for optimizing bus timetable using genetic algorithm," IOP Conference Series: Materials Science and Engineering, Vol. 166: 012016, 2017. 